\title{
After Moscow Conceptualism: Reflections on the centre and periphery and cultural belatedness
}

\section{John Roberts}

Moscow Conceptualism has since the early 1990s gained an enormous amount of critical attention in Russia, Europe and North America. Indeed, its status has risen enormously with the historical recovery and critical repositioning of the group Collective Actions, and the intellectuals, writers and philosophers who worked in collaboration with the group, or in its orbit. This is because Moscow conceptualism achieved something remarkable during the period of conceptual art's decline in Europe and America: a coherent programme of cognitive strategies, formal subtractions, and an expanded collective model of production and reception that extended the range and attributes of what we might mean by 'conceptual art' as a post-medium specific sequence of artistic manifestations. ${ }^{1}$ This points to two key issues regarding the development of conceptual art and the refunctioning and continuity of the avant-garde more generally in the 1970s:

Firstly: conceptual art was not simply a globalized phenomenon in which the message of art's 'dematerialization' (to use the familiar and clichéd term) was disseminated around the world from its intellectual 'homeland' in the US and the UK, on a kind of loose and equitable basis. On the contrary, in the wake of conceptual art's initial break with painterly modernism, 'conceptual art' came to serve very different functions and uses, as a result of the cultural, social and political circumstances in which it found itself, shifting and transforming the character and form of conceptual art itself. ${ }^{2}$ Thus in South America - particularly Argentina and Chile - conceptual art's strategies of formal negation were overdetermined by antiimperialist struggle, which included a critique of US American cultural imperialism and the US

\footnotetext{
${ }^{1}$ Octavian Esanu, Transition in Post-Soviet Art: The Collective Actions Group Before and After 1989, Central European University Press, Budapest and New York, 2013.

2 Luis Camnitzer, Jane Farver, Rachel Weiss, eds., Global Conceptualism: Points of Origin, 1950s-1980s, Queens Museum of Art, New York, 1999
} 
American neo-avant-garde itself. ${ }^{3}$ In Poland, conceptual art drew on an already vigorous dramaturgic avant-garde tradition (Jerzy Grotowski's 'poor theatre') to produce a predominantly event-based conceptual art centred mostly in the countryside centred and the suburbs, and thereby, as far as away from the industrial imaginary of Soviet socialist realism as possible and the prying eyes of the state. ${ }^{4}$ In Iceland, in the early 1970 s the recourse to text and photography was, as it was in many other peripheral national European contexts, a means of breaking from a narrow national, painterly landscape tradition. Furthermore, the concerns of UK and US conceptual art were by no means compatible themselves. Many of the interests of 'analytic conceptual art' in the UK, are very different from those in the US, given US conceptual art's reliance on an undisclosed formalist hangover from modernism (such as in the work of Joseph Kosuth), thereby weakening any assumed shared history between US and British conceptual artists. Indeed, as in other centres of national conceptual production there is an implicit assumption that much American conceptual art is turned inwards to the interests of the art market, and 'business as usual'. Thus, in the group work of Art \& Language, for instance, there was a primary concern with the intellectual division of labour and questions of cultural pedagogy, in the wake of the huge influx of working class and lower middle-class students into the art school system in the Britain in the 1960s. How might class experience relate to learning and value in art? How might a non-bourgeois subjectivity be created from the discursive opportunities of conceptual art? And how might women artists be an active part of this? ${ }^{5}$ As such, there were clear connections between these forms of group learning and the revolutionary debates on teamwork in the Soviet Union in the 1920s.

In addition, we see another set of national-cultural conditions at play in the case of Moscow Conceptualism itself, producing a 'conceptual art' quite different in its theoretic-material concerns than other centres of production. In a period of post-Thaw, and late Soviet 'stagnation', conceptual art takes the form of a generalised entropic and apophatic

\footnotetext{
${ }^{3}$ See, Inés Katzenstein, ed., Listen Here Now! Argentine Art of the 1960s: Writing of the Avant-Garde, Museum of Modern Art, New York, 2004.

${ }^{4}$ For a discussion of early Conceptual art in Poland and the flourishing of local networks and independent spaces, see Martin Patrick, 'Polish Conceptualism of the 1960s and 1970s: Images, Objects, Systems and Texts,' Third Text 15, No 54, Spring 2001, pp25-45 ${ }^{5}$ See Michael Corris ed., Conceptual Art: Theory, Myth, and Practice, Cambridge University Press, Cambridge, 2000
} 
withdrawal from the 'public sphere' and direct political engagement, in which the absences, phlegmatic silences, and textual ambiguities of conceptual art, assume a kind of moral and poetic antipode to the (failed) rhetoric of Stalinist productivism. Indeed, in Collective Actions these zero-sum manifestations, and their almost winsome indeterminancies, produce a radicalization of both late Descartes' libertine motto: 'a happy life is an unseen life', and Spinoza's rejection of 'affect' as a kind of bondage; art finds an active 'silence'. In this sense Moscow conceptualism does share certain 'allegorical' affinities with other conceptual art in Eastern Europe; primarily the opportunity that conceptual art provides for small-scale temporary interventions, subtle acts of resistance, and 'invisible' events that provide a space for art's 'withdrawal of consent'. But in the Soviet Union, this withdrawal from consent is also attached to a strong commitment to collective avant-garde values, and therefore has little time for the 'self-possessive' individualism of much other conceptual art in Eastern Europe. Thus: we might say, that whereas Polish conceptual art has no stake in - or rather refuses a stake in - the memory of the (Soviet) historic avant-garde, Moscow conceptualism saw one of its jobs as being to reclaim and defend what remained progressive about the avant-garde legacy of the 1920 s. ${ }^{6}$

All of these conceptual art manifestation - East and West, North and South - can be defined, then, as part of that great sequence of events, manifestations and intellectual horizons identifiable with 'conceptual art', yet they all put the strategies of 'conceptual' negation and denaturalization of the art object and artist to work in very different ways and with very different outcomes. This not only produces a striking unevenness to conceptual art in this period of its emergence and transformation, but also confirms the general conditions of belatedness of conceptual art's relationship to an understanding of its own avant-garde past. Each national cultural formation was working with, and through, very different cultural and historical materials on the basis of very different kinds of awareness of the avant-garde past and the recent conceptual present.

\footnotetext{
${ }^{6}$ For a critical engagement with the avant-garde legacy, see Andrei Monastyrsky, Dictionary of Moscow Conceptualism [1999], 2010, available at www.contemporary.org
} 
This takes me to my second point: Moscow Conceptualism is defined by a range of shared cultural memories of the avant-garde (given the avant-garde's constitutive legacy, $f$ marginal presence in pot-1950s official Soviet artistic history) that are grounded in a set of political and cultural conditions that are quite unlike any other national-based conceptual art, East or West, throwing into relief the complex belatedness affecting the formation and dissemination of conceptual art during this period of globalization. Conceptual art in Europe, particularly the UK and in the US, was not an unmediated transmission belt for the historic avant-garde, given that both sets of conceptual artists were far from conversant with the critical and artistic legacy of conceptual art's own anti-modernist claims: that is, very few artists at this time in the US and UK had a working knowledge of the Soviet and Berlin avant-gardes (principally because little work was published in English on the early avant-garde period, and little work was shown). Falteringly, hesitantly, then, US-UK conceptual art - through its primary critique of painterly modernism and dismissal of art as a would-be 'natural kind' - generated a loose pathway back to the post-medium and interdisciplinary claims of the early avant-garde without in fact re-historicizing conceptual art's possible links to this past (this came much later). In the Soviet Union, in contrast, despite the fact that few works from the 1920s were on permanent display, the avant-garde legacy was not only available through the rich critical literatures of the period, and shared (if oblique) memory of the revolutionary past, but significantly, was present critically in its remnant aspects and traces, in actual everyday Soviet life in the 1970s: namely, the critique of art's commodity form (given the absence of a private market for art), a residual anti-productivism (born of a post-Brezhnevite broken economy) and a commitment to a (residual) collectivism. In fact, we might stretch this sense of revolutionary remnancy even further back, to the days of High Stalinism in the mid-1930s.

Despite the increasing state oppression and curtailment of avant-garde ideology, Soviet society underwent an extraordinary period of political and ethical reconstruction, in which the building of socialist subjectivity and a new self, drew on the memory of the 1920s for its bearings. Crucial to this appeal to the 'new self' was the importance of the citizen diary, as a place where the Soviet citizen could explore his or her position in Soviet society and as such raise its interests - as Jochen Hellbeck has outlined - "above [the] paltry parochial concerns 
[of daily life] into the higher plane of historical and action."7 These 'public' diaries in the 1930s were a remarkably popular component of this mass mobilization of the 'collective self'. Indeed, on the left, the proletarian diary was defended as a key part of the factographic and documentarist turn. LEF, for example in the late 1920s encouraged every proletarian to keep a diary in order to document their place in and contribution to the revolutionary transformation of everyday life. Even if this call to self-representation was uneven (many workers feared its consequences and many felt inadequate to the task; some diaries submitted to public scrutiny were barely literate), nevertheless many workers took the opportunity to write themselves into collective life and history.

They sought to realize themselves as historical subjects defined by their active adherence to a revolutionary cause...They put pen to paper because they had pressing about themselves and they sought answers in diaristic self-interrogation. Their diaries were active tools, deployed to intervene into their selves and align them on the axis of revolutionary time. ${ }^{8}$

Thus, even after the Party had taken its distance from the interventionist and socially experimental character of the diary-programme (in a drive against bourgeois 'selfrepresentation'), there remained in place, a strong ethos of the socialized self, in which the link between writerly self-representation and life, the self and the collective, promised an authentic participation in a historical process larger than oneself. In this respect, despite the cynical narrowing of this ideal after the war, the Party sought to maintain the notion of each citizen as 'consciously' integrated into Soviet society. Moscow conceptualism, therefore, did not have to imagine the social character of the avant-garde through the creation of a micro or enclave 'communalism', in the manner of the post-1960s Western avant-garde, it could draw on its still living, if attenuated, forms and deflected agency, in the collective present. But, of course, if these conditions might enable the production of a conceptual art free from the need for the machinery of social critique and critical theory, this conceptual art was not free of its own local constraints and avant-garde belatedness.

\footnotetext{
7 Jochen Hellbeck, Revolution on My Mind: Writing a Diary Under Stalin, Harvard University Press, Cambridge Mass., and London, 2006

${ }^{8}$ Hellbeck, op cit, p5
} 
If the group Collective Actions represents the first manifestation - loosely speaking - of the avant-garde in the Soviet Union for almost 50 years, it nevertheless, had no working relationship to the socially transformative character of the historic Soviet avant-garde; officially, it was claimed, this kind of work had already been done. Indeed, in many respects Moscow Conceptualism represents the opposite: a ghostly or revenant avant-garde divorced from the avant-garde's socially constructive dynamic - precisely the condition of the avantgarde and conceptual art, or neo-avant-garde, in the West after the Second World War hence, the strange, withdrawn, oblique, indeterminate character of Moscow Conceptualism. As with Western conceptual art, conceptual art in the Soviet Union did not assume a primary field of engagement with the social and material world, but, rather, operated within the 'secondary' realm of the symbolic. In other words, Moscow conceptual art was no less distant from the fundamental structural promise of the original Soviet avant-garde - the radical dissolution of art into productive labour and productive labour into art; the transformation of the built environment; the subsumption of art into life - than was Western conceptual art at the time, despite Moscow Conceptualism's extraordinary, post-market, conditions of artistic production. This gives the work of Collective Actions, and Moscow Conceptualism generally, a haunted quality and pathos that is quite unlike any other conceptual art of the period (with the exception perhaps of work being done in Poland [Wlodzimierz Borowski, Zbigniew Warpechowski] and Czechoslovakia [Eugen Brikcius, Jan Steklik], although for quite different reasons). Its mode of production was free of the determinations of capitalist exchange (the singular commodity-form, institutional approbation, the pressure of individual careers defined by market identity and branding), yet this mode of production - art as a nexus of post-object, temporal conditions and de-reifying collective techniques - operates in a 'suspended' state. Yet, this isn't the 'suspensive' state of the Western avant-garde, divorced from a revolutionary tradition and forced to find strategies of engagement/disengagement in a culture in which bourgeois cultural pluralism diverts, ameliorates or blocks, the 'world transforming' and post-market functions of avant-garde practice. In the post-Thaw years in the Soviet Union this is a notion of 'suspension' as an actual state of withdrawal and radical non-compliance, as if participation in the official channels of cultural support was to endorse Stalinism and betray the legacy of cultural resistance since the late 1930s. As Keti Chukhrov argues: 
The "70s in Soviet society are known for economic and technological stagnation. At the same time the texture of social life in the ' 70 s is characterized by a strange spiritual pleroma [a sense of fullness] or plentitude...anti-utilitarian collective consent becomes widespread, and a society grows accustomed to abstaining from pleasures and libidinal joys, consensus seems to be reached more often, and high standards of living, for construction, technical efficiency, and consumer prosperity become less necessary. ${ }^{9}$

This places Moscow Conceptualism in an unprecedented position within the greater and uneven orbit of conceptual art during this period, for all this work's varieties of engagement: it draws on the historic Soviet avant-garde, indeed, benefits from the living interconnection between conceptual art and the remnant collectives ideologies of the 1920s under the postmarket conditions of 1970 s cultural production, yet, like many strategies of conventional modernism - that it also echoes - it withdraws backwards into the world.

This invites us, to turn, therefore, to the question of cultural unevenness and the contemporary avant-garde. If the 1970s, in Europe, North America and the Soviet Union is a period of the belated possession and re-staging of conceptual art across national-cultural formations - under the impossible and half-forgotten name of the avant-garde itself - today the re-functioning of the avant-garde in the West and in Russia is, of course, no less subject to other kinds of unevenness, but, at the same time, crucially, it is also subject to unprecedented kinds of historical consanguinity, given the global and post-Cold War character of art and the increasing global interconnection of the cultural margins. That is, if UK-US conceptual art was in some sense blind to its own avant-garde legacy, given its lack of theoretical access to the historic avant-garde, and, therefore, had to work falteringly to reconstruct this legacy and its possibilities, and Moscow conceptualism was an 'avant-garde' 'at home', so to speak, but without real transformative agency, today the avant-garde is, at least, freely available intellectually as an ongoing research programme in which the effects of the belated production and reception of the historic avant-garde are now self-consciously incorporated into a reflexive and historical understanding of the limits and possibilities avant-

\footnotetext{
${ }^{9}$ Keti Chukhrov, 'Soviet Material Culture and Socialist Ethics in Moscow Conceptualism', in Boris Groys, ed, Moscow Symposium: Conceptualism Revisited, Sternberg Press, New York, 2010
} 
garde, that is, into a model of combined and uneven artistic development. In other words, the structural belatedness and unevenness of cultural production and reception is built-into the theoretical claims of contemporary avant-garde research programmes. And this necessarily shifts the operational and temporal terms of the avant-garde, in the light of the massive changes historically and culturally since the 1920s. The avant-garde is not a thing or 'movement' to be now recovered in the light of this new intellectual and critical reflexiveness globally - as if we can now get on with the job of properly being 'avant-garde' - but rather, a set of resources and possibilities to be re-thought and re-functioned as an outcome of its defeats, struggles, hiatuses and caesurae over the last 90 years, and, therefore, something that is to be reconstructed constitutively from these hiatuses, gaps and caesurae.

Thus the avant-garde maybe be no less a "suspensive" project today, than it has been from the late 1930s, that is, no less subject to the division between art and the social world, and between aisthesis and collective experience, but under present political and social conditions, in the wake of the global crisis of capital, the intellectual demise of postmodernism, and the compression and claustrophobia of neo-liberal network culture, one of its core ideals has nevertheless returned to central stage in order to redirect a huge amount of artistic activity: the totalizing critique of capitalist relations as a condition of art's emancipatory force and legibility. For the first time, for a very long time, the relationship between art and praxis, and art and politics, art and collective experience, art and productive labour, art and free labour, the conditions of art's living situatedness, art and capital accumulation, art and universal emancipation, are becoming the working terms and grammar of huge number of artists working collectively or individually on socially engaged projects that owe little or nothing to official or market criteria. This is an enormous social and intellectual shift within the political economy of art, and therefore, is irreducible to the notion these new forms of collective, participatory, and temporal 'post-object' practice, simply represent a stylistic shift in concerns, and, therefore, will dissolve with changed social and political circumstances. On the contrary, these changes represent a massive reorientation of 'business as usual' in art, transforming the artist in classic avant-garde terms from the producer of discrete objects for exchange on the market to the producer or facilitator of relations between things, and of conceptual templates. 
Two things ensue from these new conditions of the "suspensive" avant-garde. ${ }^{10}$ Firstly, we can see clearly how much of this new practice and its recent forbears, back to Conceptual Art and beyond, owes to the world-historical rupture of Soviet Constructivism as the metaform of all avant-garde research programmes in the $20^{\text {th }}$ and $21^{\text {st }}$ centuries. All present and recent practices, consciously or not, derive from this constructivist programme: that is, they derive from the destruction of the authority of discrete object, of authorial sovereignty and monadic consciousness, of disciplinary and craft unity, of aesthetic singularity, and of the nondiscursive or aesthetic-contemplative reception of art. And, secondly, under globalization, we can see how changes in the relations and order of avant-garde belatedness have transformed the perception of cultural indebtedness across national borders, and, as such, have released cultural peripheries, in some instances, from their subaltern relationship to the centre. So, in globalized conditions of transnational exchange and collaboration the Soviet avant-garde is no longer the 'Soviet avant-garde' in conventional art historical terms (namely, that sequence of events, works, that rises in prominence, falls away and then disappear to be recovered as 'influences'), but, the enduring transformative core of art's emergence from its bourgeois prehistory; in other words, its universalizing dimension is released into the problems of contemporary practice.

Yet if Western national cultural traditions can no longer secure cultural patrimony for themselves by simply asserting the greater authority and prestige of the (the white normative) centre, this is not to say that the Anglo-American imperialist relationship between the centre and the periphery has changed how imperial capital operates; imperial capital still structures and shapes global circuits of influence and power, just as it structures finance capital's investment in the global art market to the advantage of the large Western-sales markets. But, nevertheless, in the absence of the constraints of the Cold War, and in the wake of de-colonialization, and the new forces of transcultural exchange, the alignment between imperial capital and imperial cultural power in the interests of shaping and influencing the cultural direction of national-states has diminished; the one-way traffic of modernization from centre to periphery has broken down. Peripheries remain peripheries, certainly, but

\footnotetext{
${ }^{10}$ See John Roberts, Revolutionary Time and the Avant-Garde, Verso, London and New York, 2015
} 
their peripheralness is no longer subordinate to an exoteric process of modernization. Rather, the experience of modernization on the periphery is now part of a challenge on the part of the peripheries to ruling definitions of modernization itself. That is, if the centre can no longer hold in place a Western-centric and unilinear understanding of modernization, progressive blocs in the peripheries have an unprecedented role to play in questioning and challenging the very character of modernization as part of an anti-imperialist politics. This is why cultural mimicry of the centre (Anglo-American imperialism) by the peripheries, in order that the peripheries may enter the vaunted global circuits of cultural modernity, no longer applies or no longer works, because the very terms of modernity as a globalized experience are now being shaped by the non-synchronic demands and horizons of the peripheries.

Now this contribution to the critique of imperialist modernization and modernity by various progressive blocs within various peripheral national cultures is itself dependent upon what kind of periphery the country in question is and what kinds of relationship the national culture in question has to the dynamics of global modernity. Not all peripheries have rich and extensive connections to the cultural legacies of a dynamic modernity, and, therefore, clearly not all peripheral cultures are equal contributors to the anti-imperialist dialogue. So, this is why, although the new conditions of globalization have released a groundswell of other claims to modernity from periphery to centre, this process is itself uneven, given each nation state's determinate place within the network of imperialist relations. In other words, Kinshasha is not Bombay, despite both having a subordinate place in the imperialist chain.

This is why Russia is what we might call a privileged periphery, given its prominent place in the imperial world order (as a weakened imperial power itself) and its own historical and culture connection to epochal changes in modernization and emancipatory politics. For, however, marginal at the moment the country remains culturally in relation to AngloAmerican imperialism, progressive forces are able to draw on an unprecedented set of revolutionary cultural and political resources as a part of the ongoing debate on globalization and modernization. And this is why Boris Kargarlitsky is wrong when he says, speaking of contemporary art in Russia, in an interview with Ekaterina Dergot, that "we are still living off the remainders of the Russian avant-garde legacy, relying on it as parasites... our cultural 
assets are exhausted."11 Indeed, this tone and accompanying judgement seems to me to be exactly what is not required under these transcultural conditions. For what the new avantgarde globally reveals is how Russia's position as a privileged periphery lies precisely in its capacity to act as a critical placeholder for the collective legacy of this avant-garde. This is not nostalgia, or a national propping up of an exhausted tradition, but on the contrary, a recognition that the huge transformations occurring globally in art, and, in the face of the still prevailing, if shifting, cultural unevenness of the imperial relation, the avant-garde has a 'home' in Russia, so to speak, which is demeaned at its peril. Therefore, wherever and whatever the kind of work being done on the research programmes of a new avant-garde internationally, Russia will remain a privileged space of reception for this avant-garde's claims, despite all the reactionary forces currently lined up against it.

${ }^{11}$ Boris Kagarlitsky interviewed by Ekaterina Degot, 'Fragile Authoritarianism', in Post-Post Soviet? Art, Politics \& Society in Russia at the Turn of the Decade, eds., Marta Dziewanska, Ekaterina Degot \& Ilya Budraitskis, Museum of Modern Art Warsaw, Warsaw, 2013, p144 145 
